\title{
PENGARUH INFLUENCER MARKETING DAN VIRAL MARKETING TERHADAP KEPUTUSAN PEMBELIAN BITTERSWEET BY NAJLA
}

\author{
Muhammad Miftahul Fathurrahman ${ }^{1}$, Diana Triwardhani ${ }^{2}$, Jenji Gunaedi Argo ${ }^{3}$ \\ ${ }^{1}$ Jurusan Manajemen, Universitas Pembangunan Nasional Veteran Jakarta \\ Email: muhammad.mf@upnvj.ac.id \\ ${ }^{2}$ Jurusan Manajemen, Universitas Pembangunan Nasional Veteran Jakarta \\ Email: dient_upn@yahoo.com \\ ${ }^{3}$ Jurusan Manajemen, Universitas Pembangunan Nasional Veteran Jakarta \\ Email: jenjifeb123@gmail.com
}

\begin{abstract}
Bittersweet By Najla is known as a marketer who uses influencer marketing and viral marketing methods. Although this method is known as a powerful marketing method, sales of new products marketed using influencer marketing and viral marketing are not in line with the old products that people are familiar with. This study aims to prove the influence of influencer marketing on purchasing decisions and viral marketing on purchasing decisions. This research is a descriptive quantitative study with the object of research being Bittersweet By Najla consumers in Jabodetabek. The sample is 100 respondents with purposive sampling technique. The hypothesis of this study was tested using SmartPLS 3.0 with the results (1) There is a significant influence of influencer marketing on purchasing decisions of 0.425. (2) There is a significant effect of viral marketing on purchasing decisions of 0.346 (3) There is a contribution from influencer marketing and viral marketing of $51.9 \%$, and the difference of $48.1 \%$ is obtained from other variables. (4) There is an influence of influencer marketing and viral marketing on purchasing decisions..
\end{abstract}

Keywords: Influencer marketing, Viral Marketing, Purchase Decisions

\begin{abstract}
ABSTRAK
Bittersweet By Najla dikenal sebagai pemasar yang menggunakan metode influencer marketing dan viral marketing. Meskipun metode tersebut dikenal sebagai metode pemasaran yang ampuh, penjualan pada produk baru yang dipasarkan menggunakan influencer marketing dan viral marketing tidak selaris produk lama yang telah dikenal orang-orang. Penelitian ini ditujukan untuk membuktikan pengaruh dari influencer marketing terhadap keputusan pembelian dan viral marketing terhadap keputusan pembelian. Penelitian ini berupa sebuah penelitian kuantitatif deskriptif dengan objek penelitian konsumen Bittersweet By Najla se Jabodetabek. Sampel berjumlah 100 responden dengan teknik purposive sampling. Hipotesis dari penelitian ini diuji menggunakan SmartPLS 3.0 dengan hasil (1) Terdapat pengaruh secara signifikan dari influencer marketing terhadap keputusan pembelian sebesar 0.425. (2) Terdapat pengaruh secara signifikan dari viral marketing terhadap keputusan pembelian sebesar 0.346 (3) Terdapat kontribusi dari influencer marketing dan viral marketing sebesar $51.9 \%$, dan selisihnya berupa $48.1 \%$ didapatkan dari variabel yang lain. (4) Terdapat pengaruh influencer marketing dan viral marketing terhadap keputusan pembelian.
\end{abstract}

Kata Kunci: Influencer marketing, Viral marketing, Keputusan Pembelian, Bittersweet By Najla 


\section{PENDAHULUAN}

\section{Latar Belakang}

Salah satu strategi yang digunakan oleh perusahaan untuk beradaptasi pada zaman yang berkembang ini adalah dengan menerapkan online marketing. Hal ini didukung oleh data dari sumber wearesocial.com yang menunjukkan bahwa pengguna internet di Indonesia memperoleh angka 175.4 juta atau sebanyak 64\% dari seluruh penduduk Indonesia. Oleh karena itu online marketing dinilai efektif dan potensial untuk diterapkan oleh perusahaan untuk pasar Indonesia karena banyaknya pengguna internet tersebut dan juga kemudahan berbelanja yang didapatkan (Kemp, 2020) .

Kemudahan jual beli online yang hadir dengan adanya online marketing berdampak pada keputusan pembelian dari konsumen. Menurut Romla dan Ratnawati (2018) dengan meningkatnya kemudahan konsumen dalam mengkonsumsi, tingkat kepercayaan dalam keputusan pembelian juga anak semakin meningkat, sehingga jika konsumen dapat mudah mengakses informasi-informasi yang ada di internet maka strategi-strategi pemasaran yang dipasarkan kepada konsumen tersebut secara online akan efektif untuk diterapkan.

Influencer marketing merupakan salah satu teknik pemasaran yang menggunakan influencer/kelompok referensi di media sosial untuk mempengaruhi sikap, perilaku, bahkan hingga keputusan konsumen dalam membeli barang. Para influencer membantu mengambarkan spesifikasi dan menyediakan informasi dari suatu produk untuk nantinya pilihan alternatif dapat dievaluasi. Para influencer digunakan oleh para pemasar dikarenakan jika pesan yang disampaikan dengan sumber yang menarik dan dikenal masyarakat maka akan mendapatkan respon dan perhatian yang lebih tinggi (Kotler, 2015).

Viral marketing dapat menjadi penerapan strategi pemasaran yang akurat. Saat suatu produk/jasa diterima dan menjadi viral maka produk/jasa tersebut akan dikenal masyarakat luas. Tetapi untuk sebagian masyarakat tidak hanya mempercayai sesuatu yang viral, sehingga mereka merujuk pada kelompok referensi tertentu untuk meyakinkan mereka untuk melakukan keputusan pembelian (Maruta, 2020). Viral marketing merupakan suatu pola promosi yang tersebar melalui mulut-ke-mulut dan mengarahkan konsumen itu sendiri untuk menjadi pelaku pemasaran pada barang dan jasa suatu perusahaan yang telah dirancang oleh peusahaan tersebut yang berupa informasi, suara, gambar, bahkan video (Kotler, 2015).

Teknik pemasaran berupa influencer marketing dan viral marketing di terapkan di salah satu bisnis bernama Bittersweet_By_Najla. Viral marketing dilakukan bittersweet by Najla secara konstan melalui media aplikasi Instagram dan Tiktok. Kekuatan para influencer juga dimanfaatkan oleh pihak Bittersweet by Najla, mereka mengamati orang-orang yang memiliki kemampuan untuk melakukan persuasi terhadap pengikutnya di sosial media, dan setelah menemukan influencer yang tepat mereka langsung menjalin kontrak untuk mengiklankan videonya (Bittersweet By Najla, 2021).

Bittersweet by Najla disambut pasar dengan sangat baik dan dikenal karena faktor pemasarannya yang unik yaitu dengan memanfaatkan kekuatan sosial dari influencer dan promosi besar melalui media sosial yang sering viral (Sabrina, 2020). Oleh karena itu, peneliti ingin mengetahui dan menganalisis pengaruh influencer marketing dan viral marketing terhadap keputusan pembelian Bittersweet By Najla.

Didasari oleh gap research, jurnal yang dijadikan sebagai acuan dalam proses pengolahan data adalah sebagai berikut : (Widyastuti et al., 2020) mengatakan bahwa perusahaan dapat meningkatkan penjualan yang signifikan dengan digunakannya influencer marketing. Begitu pula dengan viral marketing secara signifikan dapat mempengaruhi keputusan pembelian menurut penelitian yang dilakukan oleh (Tendean et al., 2020). Penelitian-penelitian ini juga mendapat dukungan dari (Rika \& Samatan, 2020) yang meneliti tentang viral marketing dan 


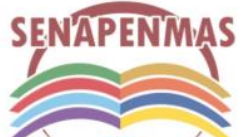

2021

Seminar Nasional Hasil Penelitian dan Pengabdian Kepada Masyarakat 2021

Pengembangan Ekonomi Bangsa Melalui Inovasi Digital Hasil Penelitian dan Pengabdian Kepada Masyarakat Jakarta, 21 Oktober 2021

influencer marketing, dan menyatakan bahwa kedua variabelnya berpengaruh terhadap keputusan pembelian secara signifikan.

\section{Rumusan Masalah}

Rumusan masalah yang didasarkan latar belakang diatas adalah sebagai berikut:

a. Apakah influencer marketing berpengaruh terhadap Keputusan pembelian di Bittersweet by Najla?

b. Apakah viral marketing berpengaruh terhadap keputusan pembelian di Bittersweet by Najla?

\section{METODE PENELITIAN}

\section{Teknik Analisis Deskriptif}

Dari penggunaan analisis data deskriptif peneliti mengharapkan hasil berupa gambaran deskriptif terutama pada variabel yang digunakan untuk menggambarkan persepsi responden terhadap pertanyaan yang diajukan oleh peneliti (Ferdinand, 2014). Penilaian yang dilakukan menggunakan teknik analisis indeks dengan skala jawaban responden seperti berikut :

Tabel 1. Skala Jawaban Responden

\begin{tabular}{cc}
\hline Nilai & Perngertian \\
\hline 1 & sangat tidak setuju \\
\hline 2 & tidak setuju \\
\hline 3 & ragu-ragu \\
\hline 4 & setuju \\
\hline 5 & sangat setuju \\
\hline
\end{tabular}

Sumber Gambar: Data diolah

Selanjutnya nilai indeks akan diproses melalui metode tiga kotak, untuk batas nilai dasar dari skala indeks adalah dari 1 hingga 10. Sehingga angka berupa indeks yang dihasilkan mulai dari angka 10 - 100 dengan rentang sebesar 90 tanpa angka 0 . Dengan penggunaan metode tiga kotak yang dilakukan, maka rentang sebesar 90 dibagi 3 menjadi 30 pada interpretasi indeks.

Tabel 2. Tabel Interpretasi Indeks

\begin{tabular}{cc}
\hline & Indeks \\
\hline Nilai & Interpretasi \\
\hline $10-40$ & Rendah \\
\hline $40-70$ & Menengah \\
\hline $70-100$ & Tinggi \\
\hline
\end{tabular}

Sumber Gambar: Ferdinand, 2014

\section{Teknik Analisis Data Inferensial}

Analisis data inferensial merupakan teknik statistik yang dipakai oleh peneliti dalam menganalisa data sampel yang hasilnya akan digunakan untuk populasi. Analisis inferensiaal yang dilakukan pada penelitian ini didapatkan dari hasil output partial least square (PLS).

Langkah-langkah yang dilakukan untuk menganalisis data dan melakukan persamaan struktural adalah : 


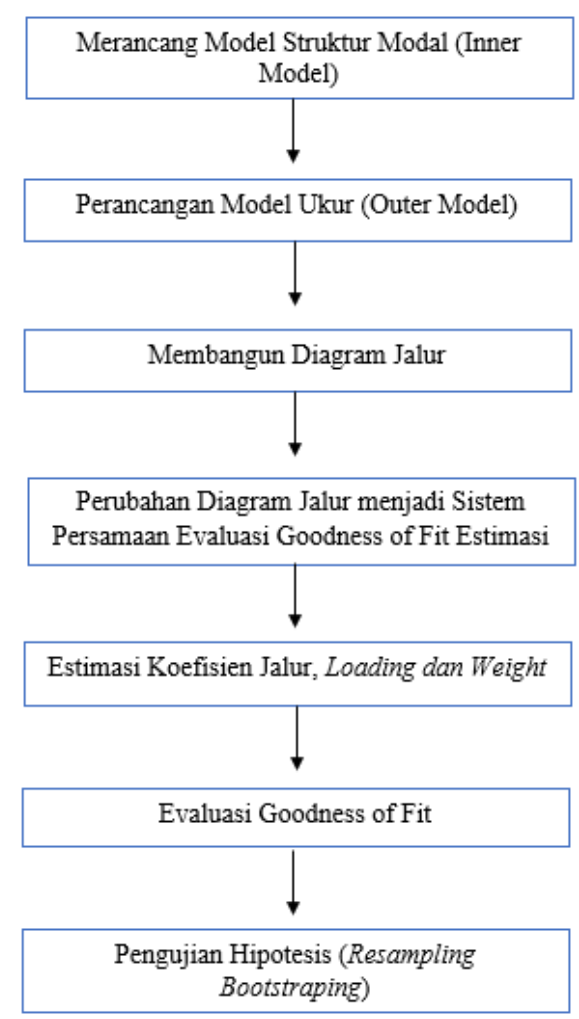

Gambar 1. Tahap Penggunan PLS

Sumber Gambar: Ghozali, 2014

\section{HASIL DAN PEMBAHASAN}

\section{Uji Validitas}

Untuk pengujian validitas, indikator reflektif menggunakan loading factor untuk convergent validity dan AVE untuk discriminant validity.

Tabel 3. Tabel Average Variance Extracted

Sumber Gambar: Hasil output SmartPLS

\begin{tabular}{cc}
\hline Variabel & Average Variance Extracted (AVE) \\
\hline Keputusan Pembelian & 0.470 \\
\hline Influencer marketing & 0.582 \\
\hline Viral marketing & 0.607 \\
\hline
\end{tabular}

Variabel keputusan pembelian memperoleh nilai AVE yang dibawah batas 0.5 yaitu 0.470 . Oleh karena itu, perlu dilakukan re-estimasi untuk merubah nilai AVE dari keputusan pembelian menjadi diatas 0.5 , berikut adalah hasil re-estimasi AVE : 
Seminar Nasional Hasil Penelitian dan Pengabdian Kepada Masyarakat 2021

Pengembangan Ekonomi Bangsa Melalui Inovasi Digital Hasil Penelitian dan Pengabdian Kepada Masyarakat Jakarta, 21 Oktober 2021

Tabel 4. Tabel Reestimasi Average Variance Extracted

Sumber Gambar: Hasil output SmartPLS

\begin{tabular}{lc}
\hline \multicolumn{1}{c}{ Variabel } & Average Variance Extracted (AVE) \\
\hline Keputusan Pembelian & 0.505 \\
\hline Influencer marketing & 0.582 \\
\hline Viral marketing & 0.607
\end{tabular}

Setelah dilakukannya re-estimasi dengan mengeluarkan instrumen KP3 dan KP10 yang memiliki nilai terkecil, maka AVE dapat dinaikkan menjadi 0.505 .

Ketiga variabel telah memperoleh nilai AVE diatas 0,5, hal tersebut dapat diartikan bahwa variabel keputusan pembelian, influencer marketing, dan viral marketing dapat dikategorikan sebagai variabel yang valid.

Tabel 5.Loading Factor

\begin{tabular}{ccc}
\hline Keputusan Pembelian $(\mathrm{Y})$ & Influencer marketing $(\mathrm{X} 1)$ & Viral marketing $(\mathrm{X} 2)$ \\
\hline KP1 $: 0,738$ & IM1 $: 0,736$ & VM1 $: 0,822$ \\
\hline KP2 $: 0,701$ & IM2 $: 0,767$ & VM2 $: 0,786$ \\
\hline KP4 $: 0,748$ & IM3 $: 0,718$ & VM3 $: 0,705$ \\
\hline KP5 $: 0,722$ & IM $4: 0,745$ & VM $4: 0,799$ \\
\hline KP6 $: 0,751$ & IM5 $: 0,745$ & \\
\hline KP7 $: 0,679$ & IM6 $: 0,821$ & \\
\hline KP8 $: 0,668$ & IM7 $: 0,775$ & \\
\hline KP9 $: 0,673$ & IM8 $: 0,820$ & \\
\hline
\end{tabular}

Sumber Gambar: Hasil output SmartPLS

Uji loading factor menunjukkan hasil bahwa tiap pertanyaan memiliki nilai diatas 0,5 yaitu valid dan memenuhi kriteria. Maka dipastikan bahwa seluruh pertanyaan pada indikator reflektif yang terdapat di kuesioner adalah valid.

\section{Uji Reliabilitas}

Uji reliabilitas dapat dilakukan dengan melakukan pengujian dengan uji composite reliability dan Cronbach alpha.

Tabel 6. Tabel Composite Reliability

Sumber Gambar: Hasil output SmartPLS

Variabel Composite Reliability

\begin{tabular}{lc}
\hline Keputusan Pembelian & 0.891 \\
\hline Influencer marketing & 0.900 \\
\hline Viral marketing & 0.788 \\
\hline
\end{tabular}


Semua variabel reflektif dapat dikatakan reliabel karena nilai yang tertera diatas 0.7. Sehingga hal tersebut menunjukkan bahwa semua pertanyaan di kuesioner yang terdapat pada variabel keputusan pembelian, influencer marketing, dan viral marketing dapat dikatakan reliabel dan relevan.

Tabel 7. Tabel Cronbach Alpha

\begin{tabular}{cc}
\hline Variabel & Cronbach Alpha \\
\hline Keputusan Pembelian & 0.861 \\
\hline Influencer marketing & 0.897 \\
\hline Viral marketing & 0.785 \\
\hline
\end{tabular}

Sumber Gambar: Hasil output SmartPLS

Semua variabel reflektif dapat dikatakan reliabel karena semua nilai Cronbach Alpha yang tertera diatas 0.7 .

\section{Uji R Square}

Hasil diatas menunjukkan bahwa nilai $\mathrm{R}$ square dari variabel keputusan pembelian adalah sebesar 0.519, yang artinya semua variabel selain keputusan pembelian yaitu influencer marketing (X1) dan viral marketing (X2) memiliki pengaruh sebesar 51.9\% terhadap variabel keputusan pembelian (Y).

\section{Uji T Statistik}

Variabel influencer marketing memiliki nilai $\mathrm{T}$ hitung senilai 3.519 pada kolom $\mathrm{t}$ statistik, dengan batas angka t tabel yaitu 1.9847 maka variabel influencer marketing dapat dikatakan berpengaruh terhadap keputusan pembelian. Dan variabel viral marketing memiliki nilai $\mathrm{T}$ hitung sebesar 2.654 pada kolom t statistik, nilai tersebut diatas dari angka t tabel sehingga dapat dikatakan bahwa variabel viral marketing berpengaruh terhadap keputusan pembelian.

Variabel influencer marketing menunjukkan angka 0.000 pada kolom $\mathrm{P}$ value yang lebih rendah dari tingkat kesalahan penelitian yaitu 0.05 , sehingga variabel influencer marketing dapat dikatakan berpengaruh terhadap keputusan pembelian. Sedangkan variabel viral marketing menunjukkan nilai $\mathrm{P}$ value sebesar 0.008 yang dimana nilai yang diperoleh tersebut lebih kecil dari 0.05 , hal tersebut menunjukkan bahwa variabel viral marketing berpengaruh terhadap keputusan pembelian.

Influencer marketing menunjukkan nilai original sampel sebesar 0.425 , yang artinya influencer marketing memiliki pengaruh positif sebesar $42.5 \%$ pada keputusan pembelian. viral marketing menunjukkan nilai original sampel 0.346 , sehingga viral marketing memiliki pengaruh positif sebesar 34.6\% terhadap keputusan pembelian. Berikut merupakan model yang diperoleh dari hasil uji hipotesis diatas : 


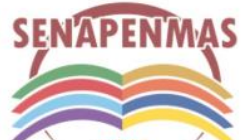

2021
Seminar Nasional Hasil Penelitian dan Pengabdian Kepada Masyarakat 2021

Pengembangan Ekonomi Bangsa Melalui Inovasi Digital Hasil Penelitian dan Pengabdian Kepada Masyarakat Jakarta, 21 Oktober 2021

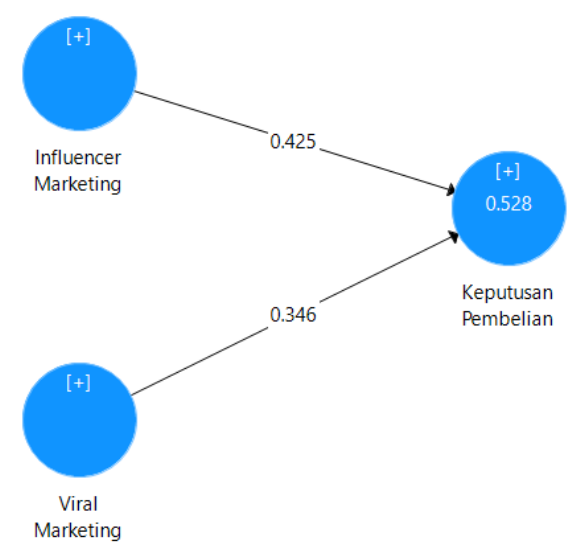

Gambar 2. Hasil Uji Hipotesis

Sumber Gambar: Hasil output SmartPLS

\section{KESIMPULAN DAN SARAN}

Setiap makalah memiliki unsur akhir yaitu kesimpulan, yang berfungsi untuk merangkum hasil dari makalah yang ditulis, serta saran sebagai rekomendasi yang dihasilkan dari dilakukannya penelitian tersebut.

\section{Kesimpulan}

Berdasarkan penjabaran pada hasil penelitian yang berjudul influencer marketing dan viral marketing terhadap keputusan pembelian Bittersweet By Najla yang menggunakan Partial Least Square dan dengan menggunakan aplikasi SmartPLS 3.0, terdapat kesimpulan dari penelitian ini sebagai berikut :

Variabel influencer marketing memiliki pengaruh positif yang signifikan terhadap keputusan pembelian Bittersweet By Najla dengan pengaruh sebesar 42.5\%, sehingga langkah Bittersweet By Najla dalam menggunakan influencer sebagai sarana alat pemasaran adalah tepat dan mendapat respon baik dari para pelanggannya. Maka semakin meningkatnya alokasi untuk para influencer sebagai alat pemasar, akan semakin tingkat keputusan pembelian pada produk Bittersweet By Najla. Hipotesis awal yang menyebutkan variabel influencer marketing dapat berpengaruh terhadap keputusan pembelian di Bittersweet By Najla dapat diterima.

Variabel viral marketing memiliki pengaruh positif dan juga signifikan terhadap keputusan pembelian Bittersweet By Najla dengan pengaruh sebesar 34.6\%, sehingga dapat ditarik kesimpulan bahwa penerapan viral marketing dari Bittersweet By Najla mendapat respon yang positif dari para pelanggannya. Hipotesis awal yang menyebutkan variabel viral marketing dapat berpengaruh terhadap keputusan pembelian di Bittersweet By Najla selaras dengan hasil dari penelitian ini dan dapat diterima.

\section{Saran}

Berdasarkan simpulan diatas, peneliti memiliki beberapa saran yang akan disampaikan, yaitu :

Untuk perusahaan, berdasarkan nilai koefisien jalur variabel influencer marketing yaitu $42.5 \%$, perlu dilakukan peningkatan alokasi pada pemasaran menggunakan influencer karena hal tersebut akan mendorong tingkat keputusan pembelian di Bittersweet By Najla. Pemilihan dari influencer yang digunakan terhadap influencer yang memiliki tingkat kepercayaan dari konsumen yang tinggi juga akan berpengaruh terhadap keyakinan para konsumen akan kredibilitas dari Bittersweet By Najla. Juga berdasarkan nilai koefisien jalur variabel viral 
marketing yaitu $34.6 \%$, maka juga perlu ditingkatkan alokasi pada pemasaran melalui Teknik viral marketing karena hal tersebut akan mendorong tingkat keputusan pembelian di Bittersweet By Najla, terutama berfokus pada seberapa besar partisipasi audiens dalam teknik viral marketing.

Untuk peneliti selanjutnya, semoga penelitian ini dapat disempurnakan dengan adanya penambahan pada variabel lain yang dapat berpengaruh terhadap keputusan pembelian. Diharapkan dengan penyempuraan yang dilakukan oleh peneliti selanjutnya, penelitian selanjutnya akan lebih akurat dan lebih maksimal.

\section{Ucapan Terima Kasih (Acknowledgement)}

Puji dan syukur penulis panjatkan kepada Allah SWT dengan segala karunia-Nya sehingga hasil skripsi ini telah berhasil diselesaikan dengan judul "Pengaruh Influencer marketing Dan viral marketing Terhadap Keputusan Pembelian Bittersweet By Najla"

Pada kesempatan kali ini penulis menyampaikan ucapan terima kasih kepada seluruh pihak yang telah membantu dalam proses penyusunan skripsi ini kepada Ibu Diana Triwardhani, SE, MM. selaku Dosen Pembimbing I dan Bapak Jenji Gunaedi Argo, SE, MM selaku Dosen Pembimbing II. serta bapak/ibu dosen yang telah membantu saya memberikan arahan dan ilmu pengetahuan yang bermanfaat bagi penulis. Semoga penelitian ini dapat memberi manfaat bagi semua pihak di masa yang akan datang.

\section{REFERENSI}

Akdeniz, C. (2015). Viral marketing Explained. Createspace Independent Pub.

Amstrong, G., et. al. (2014). Principles Of Marketing. Pearson Australia.

Amstrong, G., et. al. (2018). Principles of Marketing. In BSAVA Manual of Small Animal Practice Management and Development (11 Ed). Pearson International.

Bittersweet By Najla. (2020). Bittersweet By Najla. https://www.bittersweetbynajla.id/

Ferdinand, A. (2014). Metode Penelitian Manajemen (5th ed.). Badan Penerbit Universitas Diponegoro.

Firmansyah, A. (2019). Perilaku Konsumen : Sikap dan Pemasaran. Penerbit Qiara Media.

Ghozali, I. (2014). Metode Alternatif Dengan Partial Least Squares (PLS), Edisi 4. In Semarang: Badan Penerbit Universitas Diponegoro.

Hollensen, S. (2010). MARKETING MANAGEMENT A RELATIONSHIP APPROACH (2nd ed.). Pearson.

Kemp, S. (2020). DIGITAL 2020: 3.8 BILLION PEOPLE USE SOCIAL MEDIA. We Are Social. https://wearesocial.com/blog/2020/01/digital-2020-3-8-billion-people-use-social-media

Kertamukti, R. (2015). Strategi Kreatif Dalam Periklanan: Konsep Pesan, Media, Branding, Anggaran. PT Raja Grafindo Persada.

Kotler, P. (2015). Marketing Management 15th Edition. 15.

Kotler, P., \& Keller, K. L. (2016). Marketing Management: Global Edition (15th ed.). Pearson.

Kumar, R. (2011). Research Metodology (3rd ed.). SAGE publications.

Margis, H., \& Kavaliauskienè, Z. (2019). Impact of Influencers on a Consumer. 6 (21).

Mohammed, E. (2017). Investigating Effects Of Viral marketing On Consumer's Purchasing Decision. British Journal of Marketing Studies, 5(4), 5.

Ravichandran, M., \& Karthika, K. R. (2020). A study on impact of Viral marketing on consumer 's purchasing decisions with reference to college students, tiruchirappalli district. 5(8), 64-69.

Riduwan, M., \& Akdon, M. (2013). Rumus dan Data dalam Aplikasi Statistika. Alfabeta. 


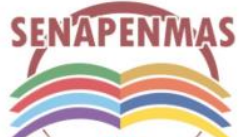

2021

Seminar Nasional Hasil Penelitian dan Pengabdian Kepada Masyarakat 2021

Pengembangan Ekonomi Bangsa Melalui Inovasi Digital Hasil Penelitian dan Pengabdian Kepada Masyarakat Jakarta, 21 Oktober 2021

Rika, R., \& Samatan, N. (2020). Pengaruh influencer marketing dan Viral marketing terhadap pengambilan keputusan penggunaan aplikasi tiktok.

Sabrina, A. (2020). Mengintip Strategi Marketing Dessert Box Bittersweet by Najla. KoinWorks. https://lokalsupportlokal.id/strategi-marketing-bittersweet-by-najla/

Sedjati, R. S. (2018). Manajemen Pemasaran (Ed 1). Deepublish Publisher.

Solis, B. (2010). Engage! The Complete Guide for Brands and Business to Build, Cultivate, and Measure Success in The New Web. John Wiley \& Sons, Inc.

Sugiyono. (2017). Metode Penelitian Kuantitatif, Kualitatif, dan R\&D. Alfabeta.

Tjiptono, F., \& Diana, A. (2019). Kepuasan Pelanggan: Konsep, Pengukuran, dan Strategi. Penerbit ANDI.

Widyastuti, S., et. al. (2020). Green Human Resource Management, Customer Environmental Collaboration and the Enablers of Green Employee Empowerment: Enhanching an Environmental Performance. 1(2).

Wijoyo, H., et. al. (2020). Digital economy dan pemasaran era new normal. Insan Cendekia Mandiri.

Williana, E., et. al. (2020). Pengaruh Influencer dan Sosial Media Instagram Terhadap Keputusan Pembelian Sate Taichan Goreng di Serpong. Volume 2, 
Seminar Nasional Hasil Penelitian dan Pengabdian Kepada Masyarakat 2021

Pengembangan Ekonomi Bangsa Melalui Inovasi Digital Hasil Penelitian dan

Pengabdian Kepada Masyarakat

Jakarta, 21 Oktober 2021

(halaman kosong) 